\title{
A Design Model of Special Vocational High School for Children with Visual Impairment
}

\author{
Johar Maknun, M. Syaom Barliana, Diah Cahyani* \\ Department of Architectural Education, Faculty of Technology and Vocational Education, \\ Universitas Pendidikan Indonesia, Jl. Dr. Setiabudi no 229, Bandung 40154, Indonesia \\ *Correspondence: E-mail: diah_cahyani@upi.edu
}

\section{A B STRACT}

This paper aimed to describe architectural design model of vocational high school that is accessible and meets the behavioral needs of children with visual impairment. The method used was a rational design method or often called as a glass box method, which was divided into four steps : 1 ) design criteria ; 2) children with visual impairment 's behaviour ; 3) programming ;4) designing model. The design criteria was combined based on its accessibility, space, sensory awareness, enhancement of learning, flexibility and ability, health and well-being condition, safety and security, sustainability, incorporation of nature environment and buildings, and availability of open space. These principle implemented from outside to inside the building , as well as from the site, landscape, building to interior of classroom. We believe that this studv gives important for the need of architectural building model for students with special needs.

\section{ARTICLE INFO}

Article History: Submitted/Received 24 Jan 2019

First revised 08 Apr 2019

Accepted 07 Jun 2019

First available online 10 Jun 2019

Publication date 01 Sep 2019

\section{Keywords:}

Special vocational high school, Visual impairment,

Model design,

Design criteria,

Education,

Learning 


\section{INTRODUCTION}

The research relating to inclusive schools have been well-documented (Morley et al., 2005; Giangreco et al., 1993; Stainback and Stainback, 1984; Reindal, 2010). In short, the researchers showed that students can get benefits and can be thought together with normal students by adding an inclusive curriculum as well as inclusive programs. By adding these strategies, students with special needs can get positive attitude (Bricker, 1995; Wolery, 1997). However, other studies showed that the schools are somewhat ineffective (Ainscow, 1997), giving ideas for the requirement in returning the students with special needs to the special program and group. This has been confirmed by the fact in the unpreparedness teachers to teach students with disabilities (Davern, 1999; Gettinger et al, 1999; Wolery et al., 1997) Further, the debate continues about the inclusive program. Then, it creates the certainty in the requirement of special education for now and in the future. Indeed, this remains the importance of special schools that can achieve equity for children with special needs (Skiba et al., 2008). In connection with the concept of education for all initiated by UNESCO, the Government of the Republic of Indonesia through Law Number 20 of 2003 concerning the National Education System Chapter IV Article 5 paragraph 2 accommodates the needs of students with physical and mental abilities who experience shortage or need special education. The Indonesian government holds special education that lead to citizens with special needs to live fairly and obtain their rights in various fields of life and livelihood.

Special education serves all students who have special problems and needs in learning. The purpose of special education is to help students with physical and/or mental disorders, to be able develop attitudes, knowledge, and skills as individuals and community members, in making reciprocal relationships with the social, cultural, and natural environment around, and can develop abilities in the world or follow further education.

Education programs in special school are related to not only aspects of knowledge but also pre-vocational and vocational programs (Harvey, 2001; Mithaug, 1985; Rasinski and Pedlow, 1994). Vocational education for Children with Special Needs (CSN) is important because it can prepare children to live more independently, do without being dependent on others, and prepare to get the job after school. However, there are small number of special schools that focus on vocational education (Edgar, 1987).

As a result, individuals with special needs experiences many challenges and difficulties in finding job or working independently after graduating from special school (Rusch et al., 2009; Test, 2004). It is caused by insufficient vocational skills to compete in the world of work or entrepreneurship. On the other hand, the community, including employers, has not yet fully provided equal opportunities and rights for prospective workers with special needs.

The recent studies described the spectrum of problems surrounding educational research for children with special needs. Researches lead to the conclusion that further explanation is required, in which the research position focused on architectural design of vocational education facilities for children with special needs is not appropriate.

Pfeiffer and Schein compared the
services of college campuses in Massachusetts and the United States in general for disabled students (Pfeiffer and Schein, 2001). In terms of accessibility, the results of the study showed that two-third of the two sample groups considered that the campus was inaccessible for them. Only $25 \%$ of Massachusetts campuses, and $37 \%$ of 
campuses nationally consider the need of accessibility. Steyn and Vlachos reported the development of vocational education and transition programs for students with intellectual disabilities in South Africa (Steyn and Vlachos, 2011). Disciplinary aspects, psychological stamina, adaptation of communication skills, attitudes towards others, use of equipment, and consistency of performance are in the varied categories between good and acceptable. The problem, i.e. the potential and ability to work of children with intellectual disabilities, is often based on medical assessment rather than vocational criteria. As a result, learning is often directed at disability and not on ability itself. Therefore, teachers, parents, and students themselves must be aware of this condition and then convince the public of their strengths and not their disabilities.

Yaeda and Snape conducted research that highlighted public policy and current practice regarding labor support, support for secondary school education services for students with special needs, and services for the transition between education and the world of work (Yaeda and Snape, 2011). They concluded that learning to improve good work behavior in CSN was difficult. The development of vocational skills in young children is a critical issue and requires good learning in real-world work situations. Continuous personal relationships with children with psychiatric disabilities are not easy, except with maximum environmental support.

Thomblin and Haring used qualitative research methods on the subject of three crew members. They reported the law on vocational education, including education for students with special needs. This law has become a reference for the implementation of education, including in general education (Thomblin and Haring, 1999). The conclusions and implications of this study confirmed that teachers in special education and general education for students with special needs must be able to bridge the gap in the transition between learning outcomes of vocational education and work.

Bell et al. presented the results of comparative researches on changing vocational education teachers for students with special needs in Finland, England, the Czech Republic, and Estonia (Bell et al., 2014). The conclusion of the research results is that vocational education for students with special needs gradually have to move from teaching in the school to the workplace, as well as considering education and testing in the world of work. In this connection, teachers must play a greater role in tutorials and counseling. Beside service profile, spectrum relevance and competence level, vocational education problem for children with special needs is the carrying capacity of educational facilities. In the provision of educational facilities for children with special needs should be facilitated, specifically, in accordance to the types of special needs.

In Indonesia, the national regulations regarding to the standard of education facilities related only to accessibility standards. Indeed, it is not enough. In general, several parameters must be added, such as dimensions of the facilities (e.g. ramp angle, street width, stair size, etc.), completeness of facilities (e.g. accessibility signs, hand railing), and buildings lay out to be easily accessed by people with disabilities, and others.

This paper aimed to describe the architectural design model for vocational learning educational facilities that are accessible and meet the behavioral needs of children with special needs. In this study, children with visual impairment were the main focus. The population in Indonesia based on national census in 2010 showed 
that the percentage of population aged of more than 10 years who experienced difficulties was $4.74 \%$. The highest type of difficulty is in visual impairment.

\section{METHODS}

The method used was a rational design method or often called as a glass box method, in which this method was adopted from reference (Vidal et al., 2004). The design phase was started by theoretically, a study of the standards of educational facilities and infrastructure for children with special needs. The standard used is the Indonesia Minister of National Education Regulation Number 33 of 2008 for Disabled Children and Children with special needs and Design for Access 2. The output of this stage is the definition of the basic principles of design that can be applied to design the practice room at Vocational High Schools for Children with VI.

The next stage is the theoretical studies and analysis of vocational competencies for children with special needs. The character and behavior of children with visual impairment is also elaborated to be applied in the design. Thus, it can accommodate them. After the design criteria can be determined, the next step is the drawing process of the special vocational high school model for children with visual impairment.

\section{RESULTS AND DISCUSSION}

\subsection{Design Criteria}

Designing criteria for education facility for Children with VI comes from the law in Indonesia Minister of National Education Regulation No. 33 of 2008 for the special education facilities. The result was also compared to 26 schools of children with special needs specifically found in 16 cities in England and 1 city in Scotland. The concept in designing a school for children with special needs refers to the characteristics and the types of disabled persons as well as the age of students.

Design for Access 2 was used as a reference for technical specifications of diffable educational facilities. It based on the results of social model of disability researches. It was examined the response of users (disabilities) to the health facilities in Manchester. The results of the research were then used as an evaluation material in the form of a design guide for improving Manchester government regulations in the form of Design for Access 2. The discussion of the research results on the conformity level between Indonesian Minister of National Education Regulation No. 33 of 2008 and the references is carried out by presenting a comparison data (See Table 1).

Based on the analysis in Table 1, it can be concluded that there are four levels of achievement: appropriate, less appropriate, inappropriate, and very inappropriate. There are only 4 of 14 indicators that reach the level of 'appropriate'. However, even for indicators that reach the level of appropriate, there are still non-attained standards compared to the criteria for educational facilities for persons with disabilities, such as in terms of sensory access and awareness. Then, 10 of 14 indicators were at less appropriate, inappropriate, and very inappropriate levels. 
Table 1. The level of conformity of the Indonesia standard for educational facilities children with special needs.

\begin{tabular}{|c|c|c|c|}
\hline No & Indicator & $\begin{array}{l}\text { Conformity } \\
\text { level }\end{array}$ & Analysis \\
\hline 1 & Site & Appropriate & In the Site indicators, national standards are compatible with references \\
\hline 2 & Building & Appropriate & $\begin{array}{l}\text { Even though it has an appropriate level, the substance of the national } \\
\text { standard does not explain the spatial structure of the building. This does not } \\
\text { meet the design criteria, namely access. }\end{array}$ \\
\hline 3 & $\begin{array}{l}\text { Parking } \\
\text { Area }\end{array}$ & $\begin{array}{l}\text { Very } \\
\text { inappropriate }\end{array}$ & $\begin{array}{l}\text { National standards are } 3 \text { (three) levels below the standard that should be. } \\
\text { It have not paid attention to parking area indicators for disabled people. }\end{array}$ \\
\hline 4 & $\begin{array}{l}\text { Road } \\
\text { crossing }\end{array}$ & $\begin{array}{l}\text { Less } \\
\text { apropriate }\end{array}$ & $\begin{array}{l}\text { National standards does not explain the technical specifications of tactile } \\
\text { Even on national road crossings, national standards have not been } \\
\text { differentiated between the presence or absence of supervision }\end{array}$ \\
\hline 5 & Pedestrian & appropriate & $\begin{array}{l}\text { Even though it is at an appropriate level, national standards does not explain } \\
\text { in detail about the guiding path. This does not meet the design criteria in } \\
\text { sensory awareness points. }\end{array}$ \\
\hline 6 & $\begin{array}{l}\text { Street } \\
\text { Furniture }\end{array}$ & $\begin{array}{l}\text { Less } \\
\text { appropriate }\end{array}$ & $\begin{array}{l}\text { Less flexible because it only has a fixed type of street furniture. So that it } \\
\text { does not meet the design criteria for points of flexibility and adaptability. }\end{array}$ \\
\hline 7 & Seating & $\begin{array}{l}\text { Less } \\
\text { appropriate }\end{array}$ & $\begin{array}{l}\text { The lack of proper seating indicators is due to the lack of details about the } \\
\text { color and completeness of the seats for the diffable. It does not meet the } \\
\text { design criteria at the points of health and comfort and consciousness of the } \\
\text { individual. }\end{array}$ \\
\hline 8 & Ramp & $\begin{array}{l}\text { Less } \\
\text { appropriate }\end{array}$ & $\begin{array}{l}\text { The technical specifications of the ramp not reached the appropriate leve } \\
\text { because they have not met the design criteria at the sensory awareness } \\
\text { point. }\end{array}$ \\
\hline 9 & $\begin{array}{l}\text { Crossing } \\
\text { Brigde }\end{array}$ & Inappropriate & $\begin{array}{l}\text { Exposure to pedestrian bridges does not take into account the needs of } \\
\text { disabled users. Thus, national standards does not meet the design criteria of } \\
\text { educational facilities. }\end{array}$ \\
\hline 10 & Stairs & Inappropriate & $\begin{array}{l}\text { Incompatibility of stairs indicators at national standards because } \\
\text { specifications of stairs does not meet design criteria in terms of access and } \\
\text { space. This is indicated by the absence of exposure that distinguishes the } \\
\text { function or type of the outer and inner stairs. }\end{array}$ \\
\hline 11 & Handrails & $\begin{array}{l}\text { Less } \\
\text { appropriate }\end{array}$ & $\begin{array}{l}\text { Handrails specifications cannot be used by all users because the dimensions } \\
\text { only for users with normal body conditions and the age of teenagers. This } \\
\text { does not meet design criteria in terms of flexibility. }\end{array}$ \\
\hline 12 & Doors & $\begin{array}{l}\text { Very } \\
\text { inappropriate }\end{array}$ & $\begin{array}{l}\text { National standards does not have attention to technical specifications } \\
\text { regarding the door for diffables. This does not meet the facility design } \\
\text { criteria for diffables. }\end{array}$ \\
\hline 13 & Lavatory & $\begin{array}{l}\text { Less } \\
\text { appropriate }\end{array}$ & $\begin{array}{l}\text { There is no provision for the diffable and does not explain the location or } \\
\text { position of the toilet in a building for education for persons with disabilities }\end{array}$ \\
\hline 14 & $\begin{array}{l}\text { Open } \\
\text { space }\end{array}$ & Appropriate & $\begin{array}{l}\text { However, national standards have not explained more detail about the } \\
\text { conditions that distinguish between open areas for diffables and open areas } \\
\text { for users in general. }\end{array}$ \\
\hline
\end{tabular}

3.2. Characteristic and Behavioral Problem in Children and Adolescent with visual Impairment

Visual disturbance is defined as a disturbance to the structure and function of the eye, causing less optimal vision (Demir et al., 2014). The inability to see in a children causes psychological disorders. Seeing is an important sensory channel in interacting with the outside world (Dale, 2007). For example, contact information is a mechanism for sharing opinions, developing mutual attention. In addition, eye contact is also very 
important for children to express and convey their emotions. Usually, children born without a lifetime vision experienced anxiety when entering adolescence. They have not only faced with the usual developmental challenges in adolescence but also additional challenges to interference.

A number of studies showed that teenagers with visible disturbance experience, emotional, and behavioral problems: lower grades in psychosocial and school functions (Wong, 2009), as well as grades in a variety of psychopathological symptoms, such as obsession compulsion, hostility, and paranoid ideation compared to normal visionary adolescents (Garaigordobil, 2009). The sufferers of compulsion obsession usually have uneasy, nervous, excessive fear, paranoid, irrationale, which keeps repeating (Smari et al., 1994). Adolescents with visual impairment tend to have a higher incidence of depression (Koenes and Karshmer, 2000) and a lower self-concept than adolescents who do not have visual impairment (Lifshitz and Weisse, 2007). To overcome the behavior of students with visual impairment, the principles of design are applied:

1. Incorporating nature environment into buildings. Studies showed that incorporating the natural environment into buildings can have a positive influence on psychological, physical and social (Wener and Carmalt, 2006)

2. Giving more portions to open spaces, where students can socialize (Perkins et al., 1992)

3. Adding eight design principles that can be applied to overcome children with visual impairment, namely; accessibility; (2) space; (3) sensory awareness; (4) enhancing learning; (5) flexibility and ability; (6) health and wellbeing condition; (7) safety and security; and (8) sustainability.

\subsection{Programming}

This stage contained planning process of space that is needed based on the standards of vocational space requirements. According to Minister of National Education Regulation No. 40 of 2008 concerning vocational Facilities, vocational buildings consist of space requirements in special vocational high school that can be described in Table 2.

Table 2. Room programming of special vocational high school for children with visual impairment .

\begin{tabular}{|c|c|c|c|c|c|}
\hline No & Area & Name of Room & Size $(\mathrm{m})$ & Number & Total $\left(\mathrm{m}^{2}\right)$ \\
\hline 1 & General learning & Classroom & $8 \times 10$ & 12 & 960 \\
\hline 2 & & Library & $8 \times 8$ & 1 & 64 \\
\hline 3 & Special Learning & $\begin{array}{l}\text { Orientation and mobilization } \\
\text { room }\end{array}$ & $5 \times 4$ & 1 & 20 \\
\hline 4 & & Communication therapy room & $5 \times 4$ & 1 & 12 \\
\hline 5 & & $\begin{array}{l}\text { Perception of sound and } \\
\text { rhythm therapy room }\end{array}$ & $8 \times 4$ & 1 & 32 \\
\hline 6 & & $\begin{array}{l}\text { Self and movement therapy } \\
\text { room }\end{array}$ & $8 \times 4$ & 1 & 32 \\
\hline 7 & & Headmaster room & $8 \times 8$ & 1 & 16 \\
\hline 8 & & Teacher room & $10 \times 110$ & 1 & 100 \\
\hline 9 & & Administration room & $5 \times 5$ & 1 & 25 \\
\hline 10 & & Mosque & $20 \times 20$ & 1 & 400 \\
\hline 11 & & Medical room & $4 \times 4$ & 1 & 16 \\
\hline
\end{tabular}


Table 2 (continue). Room programming of special vocational high school for children with visual impairment.

\begin{tabular}{|c|c|c|c|c|c|}
\hline No & Area & Name of Room & Size (m) & Number & Total $\left(\mathrm{m}^{2}\right)$ \\
\hline 12 & \multirow{15}{*}{ Supporting } & Consoling room & $4 \times 4$ & 1 & 16 \\
\hline 13 & & Student room & $4 \times 4$ & 1 & 16 \\
\hline 14 & & Diffable toilet & $3 \times 2$ & 25 & 125 \\
\hline 15 & & Janitor & $1.5 \times 1$ & 10 & 30 \\
\hline 16 & & Store & $5 \times 5$ & 2 & 50 \\
\hline 17 & & Basketball field & $2 \times 14$ & 2 & 364 \\
\hline 18 & & Security room & $3 \times 2$ & 2 & 6 \\
\hline 19 & & Canteen & $9 \times 2$ & 1 & 18 \\
\hline 20 & & Parking area (motorcycle) & $14.4 \times 6$ & 2 & 172.8 \\
\hline 21 & & Parking area (car) & $10 \times 2$ & 2 & 40 \\
\hline 22 & & Changing room & $2.5 \times 6$ & 4 & 60 \\
\hline 23 & & School guard & $3 \times 3$ & 1 & 9 \\
\hline 24 & & Science lab & $8 \times 8$ & 1 & 64 \\
\hline 25 & & Computer lab & $8 \times 8$ & 3 & 192 \\
\hline 26 & & Engineering drawing lab & $8 \times 8$ & 1 & 64 \\
\hline 27 & \multirow{11}{*}{$\begin{array}{l}\text { Room of } \\
\text { Vocational } \\
\text { Learning }\end{array}$} & Practice room of weaving & $8 \times 8$ & 1 & 64 \\
\hline 28 & & Oppress room & $8 \times 8$ & 1 & 64 \\
\hline 29 & & Wet printing & $8 \times 8$ & 1 & 64 \\
\hline 30 & & Material process & $4 \times 8$ & 1 & 24 \\
\hline 31 & & Manual forming & $6 \times 8$ & 1 & 48 \\
\hline 32 & & Swivel area & $4 \times 8$ & 1 & 32 \\
\hline 33 & & Individual room & $6 \times 8$ & 2 & 96 \\
\hline 34 & & Collective room & $10 \times 8$ & 3 & 240 \\
\hline 35 & & Music concert room & $12 \times 12$ & 1 & 144 \\
\hline 36 & & Record room & $8 \times 8$ & 2 & 128 \\
\hline 37 & & Storage & $8 \times 8$ & 2 & 128 \\
\hline 38 & \multirow[t]{5}{*}{ Outdoor facilities } & amphitheater & $20 \times 50$ & 1 & 1000 \\
\hline 39 & & Retention pool & $20 \times 10$ & 1 & 200 \\
\hline 40 & & Healing garden & $5 \times 10$ & 4 & 200 \\
\hline 41 & & Green house & $15 \times 8$ & 1 & 120 \\
\hline 42 & & Tenniss court & $24 \times 14$ & 1 & 336 \\
\hline 43 & \multirow[t]{3}{*}{ Supporting room } & Art gallery & $10 \times 10$ & 1 & 100 \\
\hline 44 & & Standard toilet & $1.5 \times 2$ & 10 & 30 \\
\hline & & & & Total & $5,577.8$ \\
\hline
\end{tabular}

\subsection{Designing}

The design process of special vocational high school should consider eight main principles: (1) accessibility, (2) space, (3) sensory awareness, (4) enhancing learning; (5) flexibility and ability, (6) health and wellbeing condition, (7) safety and security, and (8) sustainability. This is different from other school (Paramita et al., 2016).

Then, special school should consider access for arrival and departure. Convenient routes and mileage make life easier for children with visual impairment, especially for those who use or need mobility aids, sensory, and learning disabilities. The exact requirements depend on the school's specific arrangements and who come to the school. Children may come on foot, bike, and maybe use a wheelchair or other mobility aids. Some students use public or private transportation. Thus, designers need to find the potential number of vehicles entering or stopping. An overview of accessibility is shown in Figure 1. 


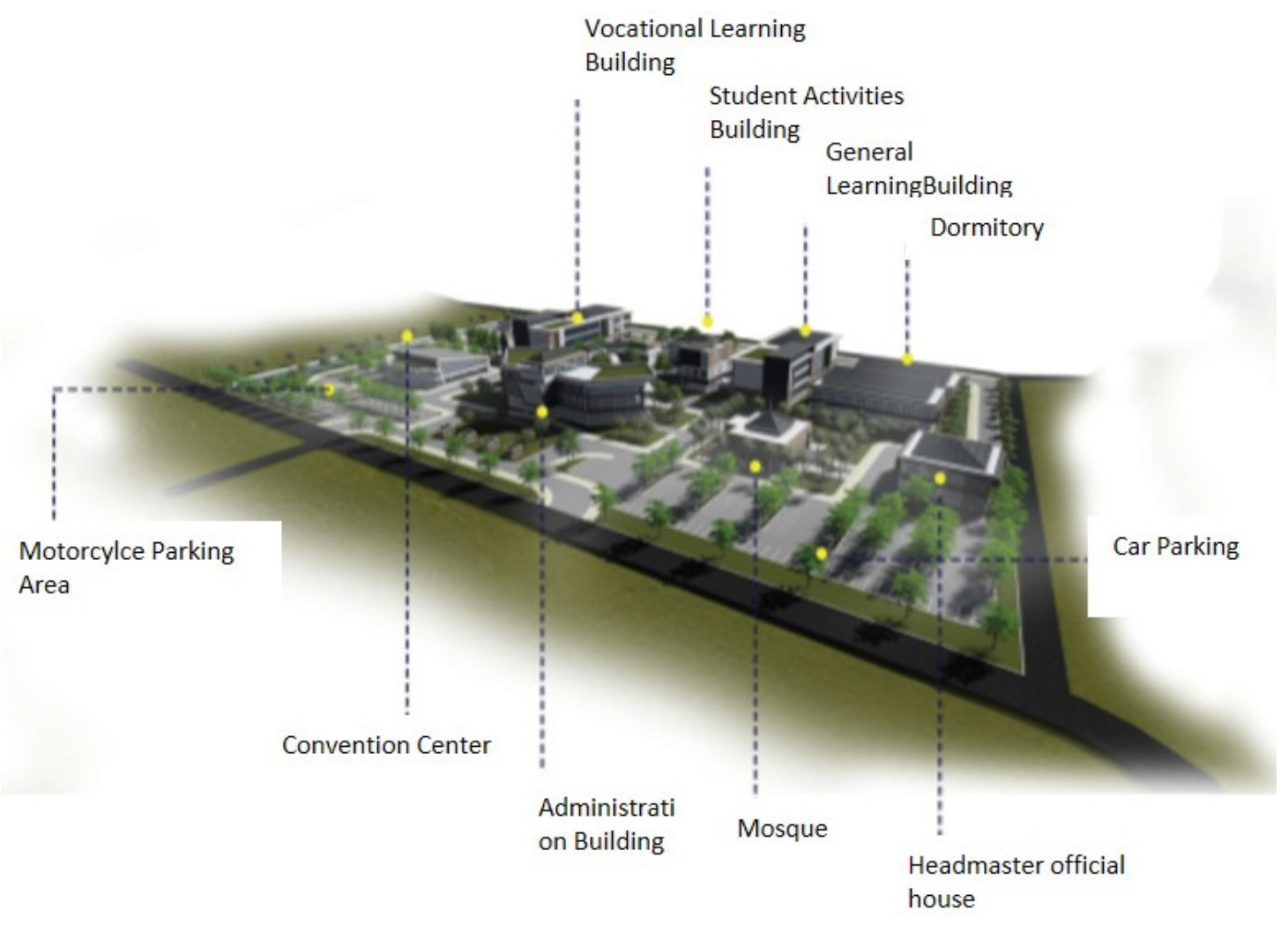

Figure 1. Perspective of special vocational high school for visual impairment.

The design of building from gate to building entrance should be:

1. Circulation of motorized vehicles that allow public and private transportation, including reductions and decreases without congestion (for example, one direction or traffic flow), and making provisions for emergency access and maintenance.

2. Pedestrian routes safety. Some people are less aware of the risk of traffic (or cannot see/hear the vehicle) and this must be considered when the site is planned.

3. Easily accessible, anti-slip levels or surfaces, and non-slippery surfaces (or awake when wet) along the route, without danger of travel and with easyto-reach walking routes to make choices.

4. Appropriate car park with easily accessible near the entrance
5. Good external lighting for routes, clear markers or markers, visual contrast, and sensory ways to help free movement.

Figure 1 shows the principle of health and well condition, sustainability, and design that can accommodate the open space in environment into the school buildings and landscape. Motorized vehicles are given parking spaces on the front of the site, in which this is with the aim of reducing air pollution. Windows can be opened so that air can freely enter into classrooms. This has a healing effect. The physical environment constantly affects students and believed to release the stress (Hartig and Marcus, 2006).

The spaces for teaching and learning activities must consider the general behavior and character of visual impairment children (see Figure 2). Some children with special needs require more space to move around with and without special equipment. Then, there must be rooms for: 
1. Safe vehicle movements.

2. Safe distance between furniture and equipment, especially for wheelchair users.

3. Additional staff room that works in a study room or other special room.

4. Storage for learning tools.

Figure 2 describes the landscape elements to give sensory awareness to children with visual impairment. The use of plant material and textured road will provide and stimulate students with visual impairment. Different materials provide different sound effects for recognizing the environment without seeing it (Schenkman, 1987; Passini and Proulx, 1988).

The special school must also consider special sensors:

1. Good quality of acoustics.

2. Appropriate level of glare-free lighting.

3. Visual contrast and texture which can be used to find sensory ways.

4. Reduce the level of stimulation to provide a calming background for learning.

5. Sensory elements using therapeutic color, light, sound, texture, and aroma, especially for children with complex health needs.

Learning enhancements can be achieved by considering:

1. Teachers and children can communicate clearly.

2. Working area that is easily accessible with space for study aids and joint assistants.

3. Furniture and equipment that support various learning and teaching styles.

4. Easy access to ICT-specific resources, personal items, assistive devices and mobility equipment.

Figure 3 shows equipment and furniture both inside and outside the classroom. It must be equipped with the guiding block that gives information of situation of the room. The information of classroom can be found in the hand railing along corridor. Meanwhile, the door handles can be reached in all conditions for all students.

The flexibility and ability principle is applied in this design. It can be seen in the use furniture. Table used can also accommodate student who use wheelchair. Furthermore, a light material of furniture must be also easily moved according to the learning process needs.

Children with special needs require more space for moving around, using some equipment, and communicating. They also need for their personal space (Rimmer et al., 2004). Thus, the classroom must be wider compared to the normal classroom. 
167| Indonesian Journal of Science \& Technology, Volume 4 Issue 2, September 2019 page 158-170
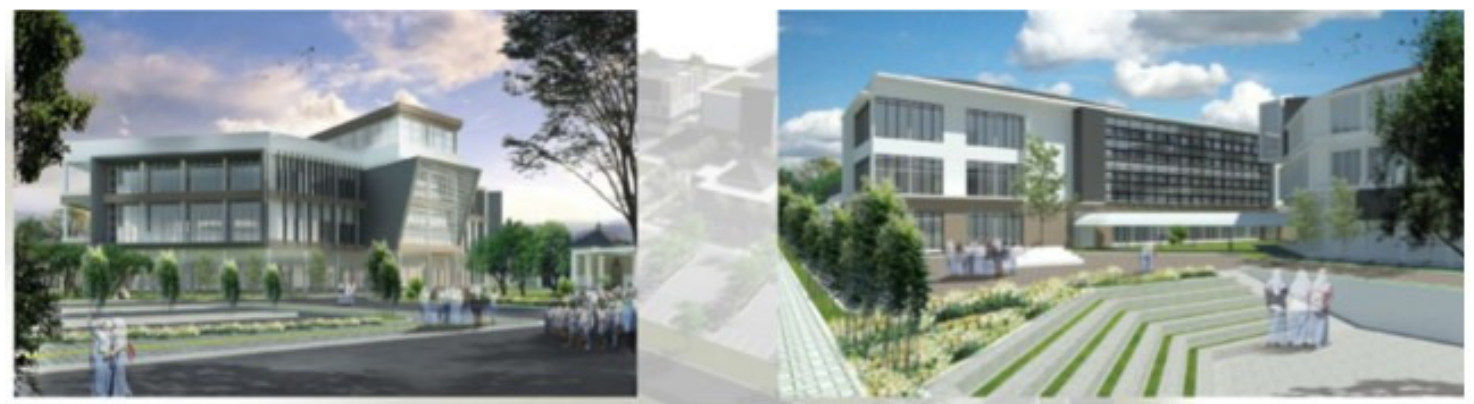

Administration Building

General Learning Building

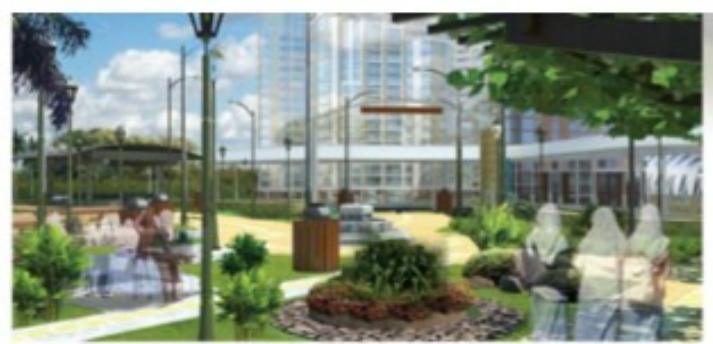

Healing Garden

Figure 2. Design of facilities in special vocational high school
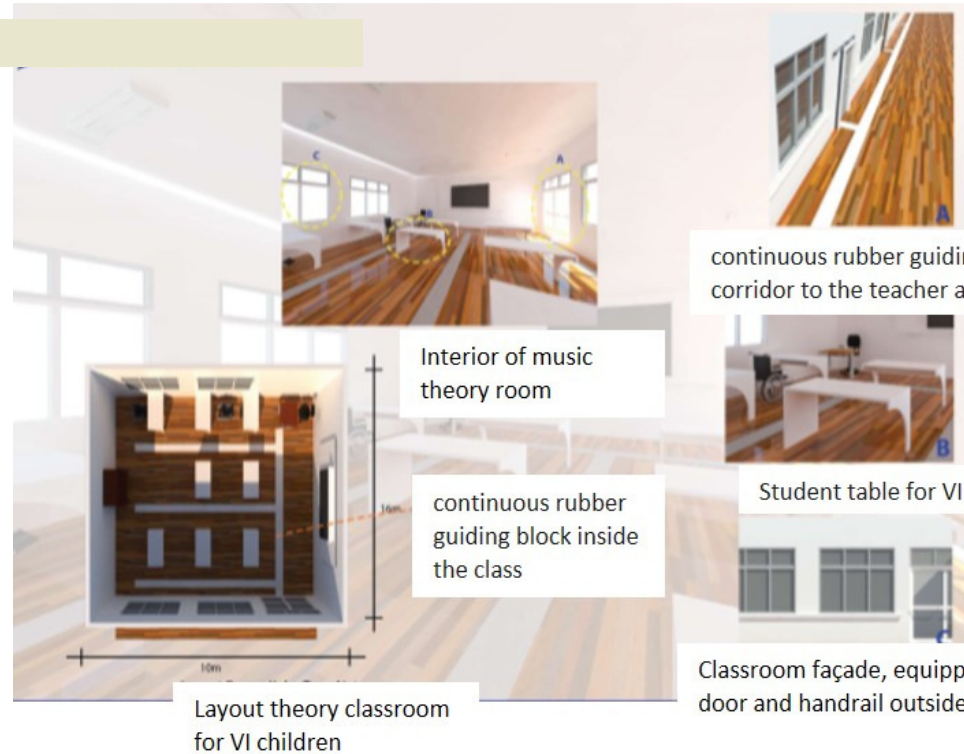

continuous rubber guiding block from the corridor to the teacher and student table

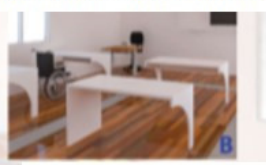

Student table for VI children

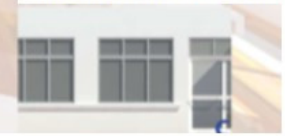

Classroom façade, equipped with windows, door and handrail outside

Figure 3. Example of music theory room with equipment and furniture for VI children. 


\section{CONCLUSION}

The Indonesian Standard for special education facilities is not yet appropriate compared to the references. The designed criteria used for designing model of special vocational high school for children with visual impairment are: 1) accessibility; 2) space; 3) sensory awareness; 4) enhancing learning; 5) flexibility and ability; 6 ) health and well-being condition; 7) safety and security; and 8) sustainability; 9) Incorporating nature environment into buildings; and 10) availability of open space.

\section{ACKNOWLEDGEMENTS}

This paper is part of the research funded by Ministry of Research, Technology and Higher Education 2017-2018. This study involved the Department of architectural education student at Universitas Pendidikan Indonesia. Furthermore, we acknowledged our students: Nurul Qolby, Elin Lestari, Hani Hidayanti, Hilmi Amrullah, and Hafiz Nurrahman.

\section{THE AUTHOR'S NOTES}

The authors declare that there is no conflict of interest regarding the publication of this article. Authors confirmed that the data and the paper are free of plagiarism.

\section{REFERENCES}

Ainscow, M. (1997). Towards inclusive schooling. British Journal of Special Education, 24(1), 3-6.

Bell, S., Hirvonen, M., Kukemelk, H., Pancocha, K., Vadurova, H., and Hion, P. (2014). The inclusion of students with special educational needs in vocational education and training: a comparative study of the changing role of SEN teachers in the European context (Finland, England, The Czech Republic and Estonia). Socialiniai Tyrimai, (2), 21-25.

Bricker, D. (1995). The challenge of inclusion. Journal of early intervention, 19(3), 179-194.

Dale N, Salt A. (2007); Early support developmental journal for children with visual impairment: the case for a new developmental framework for early intervention. Child: care, health and development, 33(6), 684-690.

Davern, L. (1999). Parents' perspectives on personnel attitudes and characteristics in inclusive school settings: Implications for teacher preparation programs. Teacher Education and Special Education, 22(3), 165-182.

Demir, T., Bolat, N., Yavuz, M., Karacetin, G., Dogangun, B., Kayaal, L., (2014), Attachment Characteristics and Behavioral Problems in Children and Adolescents with Congenital Blindness. Nöro Psikiyatri Arşivi, 51, 116-121.

Edgar, E. (1987). Secondary programs in special education: Are many of them justifiable?. Exceptional Children, 53(6), 555-561

Garaigordobil, M., and Bernarás, E. (2009). Self-concept, self-esteem, personality traits and psychopathological symptoms in adolescents with and without visual impairment. The Spanish journal of psychology, 12(1), 149-160.

Gettinger, M., Callan Stoiber, K., Goetz, D., and Caspe, E. (1999). Competencies and training 
169 | Indonesian Journal of Science \& Technology, Volume 4 Issue 2, September 2019 page 158-170

needs for early childhood inclusion specialists. Teacher Education and Special Education, 22(1), 41-54.

Giangreco, M. F., Dennis, R., Cloninger, C., Edelman, S., and Schattman, R. (1993). "I've counted Jon": Transformational experiences of teachers educating students with disabilities. Exceptional Children, 59(4), 359-372.

Hartig, T., and Marcus, C. C. (2006). Essay: Healing gardens-places for nature in health care. The Lancet, 368, S36-S37.

Harvey, M. W. (2001). Vocational-technical education: A logical approach to dropout prevention for secondary special education. Preventing School Failure: Alternative Education for Children and Youth, 45(3), 108-113.

Vidal, R., Mulet, E., and Gómez-Senent, E. (2004). Effectiveness of the means of expression in creative problem-solving in design groups. Journal of Engineering Design, 15(3), 285-298.

Koenes, S. G., and Karshmer, J. F. (2000). Depression: A comparison study between blind and sighted adolescents. Issues in Mental Health Nursing, 21(3), 269-279.

Lifshitz, H., Hen, I., and Weisse, I. (2007). Self-concept, adjustment to blindness, and quality of friendship among adolescents with visual impairments. Journal of Visual Impairment and Blindness, 101(2), 96-107.

Mithaug, D. E., Horiuchi, C. N., and Fanning, P. N. (1985). A report on the Colorado statewide follow-up survey of special education students. Exceptional Children, 51(5), 397-404.

Morley, D., Bailey, R., Tan, J., and Cooke, B. (2005). Inclusive physical education: Teachers' views of including pupils with special educational needs and/or disabilities in physical education. European Physical Education Review, 11(1), 84-107.

Paramita, B., Kamilia, I., Nurhidayat, M. I., and Ocktaviyane, R. (2016). Optimization of Design and Planing VHS Building Using Chronolux. Indonesian Journal of Science and Technology, 1(2), 170-184.

Passini, R., and Proulx, G. (1988). Wayfinding without vision: An experiment with congenitally totally blind people. Environment and Behavior, 20(2), 227-252.

Perkins, D. D., Meeks, J. W., and Taylor, R. B. (1992). The physical environment of street blocks and resident perceptions of crime and disorder: Implications for theory and measurement. Journal of environmental psychology, 12(1), 21-34.

Pfeiffer, D., and Schein, A. (2001). A comparative study of services to disabled students in public colleges and universities in the United States and in Massachusetts. Disability Studies Quarterly, 21(1), 1-10.

Rasinski, K. A., and Pedlow, S. (1994). Using Transcripts to Study the Effectiveness of Vocational Education. Journal of Vocational Education Research, 19(3), 23-43.

Rusch, F. R., Hughes, C., Agran, M., Martin, J. E., and Johnson, J. R. (2009). Toward self-directed learning, post-high school placement, and coordinated support constructing new transition bridges to adult life. Career Development for Exceptional Individuals, 32(1), 5359. 
Rimmer, J. H., Riley, B., Wang, E., Rauworth, A., and Jurkowski, J. (2004). Physical activity participation among persons with disabilities: barriers and facilitators. American journal of preventive medicine, 26(5), 419-425.

Reindal, S. M. (2010). What is the purpose? Reflections on inclusion and special education from a capability perspective. European journal of special needs education, 25(1), 1-12.

Schenkman, B. N. (1986). Identification of ground materials with the aid of tapping sounds and vibrations of long canes for the blind. Ergonomics, 29(8), 985-998.

Skiba, R. J., Simmons, A. B., Ritter, S., Gibb, A. C., Rausch, M. K., Cuadrado, J., and Chung, C. G. (2008). Achieving equity in special education: History, status, and current challenges. Exceptional Children, 74(3), 264-288.

Smári, J., Sigurjónsdóttir, H., and Sæmundsdóttir, I. (1994). Thought suppression and obsession-compulsion. Psychological Reports, 75(1), 227-235.

Stainback, W., and Stainback, S. (1984). A rationale for the merger of special and regular education. Exceptional children, 51(2), 102-111.

Steyn, G. M., and Vlachos, C. J. (2011). Developing a Vocational Training and Transition Planning Programme for intellectually disabled students in South Africa: A case study. Journal of Social Sciences, 27(1), 25-37.

Test, D. W. (2004). Invited commentary on Rusch and Braddock (2004): One person at a time. Research and Practice for Persons with Severe Disabilities, 29(4), 248-252.

Tomblin, M. J., and Haring, K. A. (1999). Vocational training for students with learning disabilities: A qualitative investigation. Journal of Vocational Education and Training, 51(3), 357-370.

Wener, R., and Carmalt, H. (2006). Environmental psychology and sustainability in high-rise structures. Technology in Society, 28(1-2), 157-167.

Wong HB, Machin D, Tan SB, Wong TY, Saw SM. (2009); Visual impairment and its impact on health-related quality of life in adolescents. Am J Ophthalmol, 147, 505-511.

Wolery, M. (1997). Encounters with general early education: Lessons being learned. Journal of Behavioral Education, 7(1), 91-98.

Yaeda, J., and Jindal-Snape, D. (2011). Post-school transition of students with disabilities: The Japanese experience. International Journal of Humanities and Social Science, 9(17), 112117. 